\title{
The National Library of Education
}

\author{
by Nancy L. Floyd
}

\begin{abstract}
The National Library of Education is the largest federally funded library in the world devoted entirely to education. In March 1994, Congress created this new national library, bringing together the former U.S. Department of Education Research Library; the 1-800 user service; INet (ED/OERI's Internet site and services); and the Technology Resources Center. These units now operate in partnership with the ERIC to carry out reference and referral services; collection and technical services; resource sharing and cooperation, including Internet Services (INet); and marketing/public relations.

NLE is planning a network of national education technology and related resources. The network will promote greater cooperation and resource sharing among education and library professionals, policymakers, the public and other providers and repositories of education information in America. It will also apply information science, computer and telecommunications technologies for the enhancement of education information dissemination.
\end{abstract}

In March 1994, Congress authorized a new national library-the National Library of Education. The legislation creating this national library was proposed by U.S. Congressman Major Owens (D-NY), a former librarian. On behalf of the Library, he said,

As the U.S. Department of Education strives to fulfil its mission to reform and improve American schools, it must have the expert assistance that only the National Library of Education can provide to make the latest knowledge about the best educational practices coherent and readily accessible to teachers, parents, school administrators, and educational researchers.

He also noted,

The U.S. Department of Education is our national engine for educational excellence, and we look to the National Library of Education to provide the fuel.

\section{Mission}

The new National Library of Education is to be a one-stop shop for all information and referral on education in the country. Its customers - students, educators, and researchers at all levels - will benefit from the Library's collection, preservation, and use of research and other education-related information. The Library will promote widespread access to its materials and expand its coverage. With other major libraries, schools, and educational centers across the United States, it will provide a network of national education resources.

\section{History}

The new library had a head start. The U.S. Department of Education already had an Education Research Library. In fact, the Research Library was the largest federally funded library in the world devoted entirely to education. This collection on education began a century ago with Henry Bamard's private collection of American schoolbooks and was nurtured by Commissioner John Eaton during his tenure (1870-1886). Several private donors further enriched the collection.

More recently, other special collections were added to the Library. Material from the former National Institute of Education, the former U.S. Office of Education, and the U.S. Department of Education, including reports, studies, manuals, and other documents, and archives of the former U.S. Office of Education and National Institute of Education, including speeches and policy papers, were added.

\section{Collections}

Today, the National Library of Educationhouses onsite more than 200,000 books and about 900 periodicals in addition to studies, reports, Educational Resources Information Center (ERIC) microfiche, and CD-ROM databases. Currently, it holds books on education, management, public policy, and related social sciences; dictionaries, encyclopedias, handbooks, directories, abstracts, indexes, and legal and other research sources in print and CD-ROM; current and historical journals and newsletters; and more than 450,000 microforms. The Library also has a legislative reference service that maintains the Department's historical record of legislation affecting education. 
Special Collections. The earliest volumes of the Library's special collections date to the fifteenth century and include early American textbooks, children's books, and books about education. Other special collections include rare books published before 1800, mostly in education; historical books (1800-1964), early American textbooks (1775-1900), modern American textbooks (1900-1959), U.S. Department of Education reports, bibliographies, and studies; archived speeches, correspondence, policy papers, and reports; and children's classics.

Since its establishment, NLE has rewritten its Collection Development Policy, as mandated by the legislation, to reflect the expanded scope of the Library. The Policy outlines the scope of the collection, describes in detail how priority levels will be assigned in future book selection, defines the Library's users, and designates what services are appropriate to a National Library. Along with this, procedures are well on the way for setting up an online public access catalog, essential if the Library is to reach out to a larger audience like its models, the National Library of Medicine and the National Agriculture Library.

\section{Services}

In a recent reorganization of the Office of Educational Research and Improvement (the unit of the Department in which the Library is organizationally located), consolidations were made, greatly expanding the available resources of the Library. The legislation had mandated that the Education Information Branch, which operated a toll-free information and free publications line, be merged with the new Library. This merge brought to the Library additional staff with a wide range of educational subject expertise. At the same time, the Department's INet (Internet/World Wide Web) system and the Educational Resources Information Center (ERIC) came on board. The ERIC unit includes 16 Clearinghouses specializing in all aspects of education, adjunct clearinghouses, and support components (ACCESS ERIC, AskERIC, ERIC Document Reproduction Service, and ERIC Processing and Reference Facility).

All these new resources have enhanced the Library's services to its customers. In its Reference and Information Services Division, the Library now fields more than 200 phone calls, up to 500 letters, and hundreds of electronic queries daily. This increased volume is being handled by staff rotation. Also due to the reorganization a Technology Resources Center has become part of the Library. This Center is one of the best kept secrets of the educational technology world. Here, hundreds of CD-ROM and other educational technology media, equipment, and software tools are on loan from vendors. Library staff demonstrate the programs and equipment to Department staff and visitors from outside, ranging from local school personnel to officials of foreign govemments.
Task Force

In the summer of 1995, a National Library of Education Advisory Task Force was named by the Secretary of Education. This has met twice in Washington, DC, and a third meeting took place at the end of July 1996 in Los Angeles. These meetings will result in a set of recommendations outlining the future direction of NLE.

\section{Public Relations}

Early on, the Library's management knew that for the new Library to fulfil its mission, it first had to let people know that it was there. So they effected a strong marketing and public relations plan. This included publishing its own products such as posters and bookmarks. Also, as part of its public relations plan, Library staff began giving monthly orientation talks, including overhead charts and informative handouts, for all new Department employees.

By the end of January 1995, staff published its first bimonthly newsletter. The newsletter includes not only recent book acquisitions but also sections on new technology, online resources, new sources from ERIC, bibliographies, on topics of current interest, maps, and other useful or newsworthy information for users, such as parental involvement in education, family literacy, and at-risk students. The newsletter is distributed Department wide and to a selected mailing list. Copies are also available at the circulation desk in the Library. A series of Fact Sheets on a variety of library-related topics are also available by phone, fax, and e-mail. These can also be found on NLE's World Wide Web Home page (http://www.ed.gov/NLE). The Library has also published the U.S. Department of Education World Wide Web Server Standards and Guidelines and will soon begin publishing a series entitled Advances in Education Research.

During National Library Week 1995, the National Library of Education celebrated its official inauguration with an Open House celebration where the Assistant Secretary for the Office of Educational Research and Improvement Sharon P. Robinson unveiled the commemorative poster. Secretary Robinson spoke to a gathering of Department staff, public, and press, saying "There's a pretty well-established appreciation for a federal role in education to provide knowledge and equal access to information. . .the library's future is secure."

Library staff followed the Open House with the first in a series of quarterly lectures featuring notable speakers on libraries, information, and technology. The lectures informed educators, teachers, researchers, librarians, and parents on issues of concern. Angela Gasparro from the Division of Libraries in the Philadelphia School District spoke on "Libraries, Technology, and Vistas of Tomorrow;" Dr. William G. Durden of the Institute for the Academic Advancement of Youth at Johns Hopkins 
University discussed "The Optimal Match: Common Sense in an Uncommon Environment," and Cheryl Graunke from the Congressional Research Service of the Library of Congress talked about "Cybrarianship: The Internet Revolution in Libraries." The fall lecture featured Dr. Galen Godbey, Executive Director of Lehigh Valley Association of Independent Colleges, who spoke on "The Agility Paradigm: How business, government, and industry must and can change to adapt to the global economy." This summer, Dr. Carolyn Sumners, Director of Astronomy and Physics for the Houston Museum of Natural Science, spoke on "Making Space for the Girls, or Finding Physics for Females."

To reach out to the education community, the Library has put itself at the forefront of the Department's strategic partnership with the Philadelphia city schools. Library staff have been working with the city's school library personnel on developing in-service training for librarians. In addition, Library staff have formed a partnership with a Baltimore school district to enhance teacher training. The Library has also made a special effort to be represented at library and information technology conferences and exhibits. Furthermore, the Library has been proactive in emphasizing customer service, developing a Customer Service Survey to provide feedback on what services are being used, what is needed, and how services can be improved.

\section{Networking}

A Division of Resource Sharing and Cooperation has been established in the Library that handles INet (the Department's public access Internet site), the toll-free electronic Bulletin Board System, and data tape sales. This Division has liaisons with a number of other information technology groups both in and outside the Department. The task for this Division will be to expand the Library's cooperative partnerships and resource sharing. Staff will look into ways to incorporate electronic resources and access to information, laying the groundwork for NLE to become a part of a major network of education resources nationwide.
NLE is in the planning stages of setting up a network to bc known as the U.S. Education Information Network (USEIN) to provide a forum for discussion of education issues, to take a leadership role in forming a national information policy as related to education, and to make recommendations to NLE on information matters. The Network will attempt to strengthen education libraries and information services of all types and to promote cooperation and communication among its members.

\section{For Your Information}

The National Library of Education offers its customers a CD-ROM catalog of the Library's collection, individual study rooms, self-service photocopier, microform reader printers, and group and individual orientation seminars. Located on the street level, it is easily accessed by the physically disabled. The Library is open 9:00 a.m. to 5:00 p.m. Monday through Friday except federal holidays.

The Library is located in Washington, DC, two blocks west of Union Station, Red Line Metro stop. The mailing address is National Library of Education, U.S. Department of Education, 555 New Jersey Avenue NW, Washington, DC 20208-5721.

The views expressed in this article are part of ongoing research and analysis at the Office of Educational Research and Improvement and do not necessarily reflect the position of the U.S. Department of Education.

Nancy Floyd is the writer, editor and Public Relations Director of the National Library of Education, U.S. Department of Education, Washington, D.C. She has previously taught French in high school and has worked as a school and special librarian, newspaper columnist and magazine editor.

nfloyd@inet.ed.gov 